\title{
A New Idea for LNG Trade: Enhancing Market Competition through a Tanker-Based Trading System
}

\author{
Satoru Hashimoto* \\ Faculty of Economics, Teikyo University, Japan
}

\begin{abstract}
This study proposes a new idea for liquefied natural gas (LNG) trade based on Japan's natural gas market. As part of their high rate of economic growth in recent decades, many Asian countries, including Japan, have constructed natural gas supply chains that are characterized by natural monopolies and vertically integrated companies. In addition, although Japan has a 50-year history of LNG imports, its domestic natural gas distribution mechanisms are not designed to create connections among markets. Therefore, domestic spot and futures markets have never operated efficiently. To promote Japanese domestic market competition, this study proposes a "tanker-based trading system" involving LNG tankers owned by a consortium of Japanese firms and supported by the Japanese government. This trading system would enhance the market efficiency of LNG-based operating countries. Thus, a spot market for natural gas in Japan and East Asia can be created using LNG tankers, and the natural gas trading system in Japan can play a role in spot markets similar to the Henry Hub and the National Balancing Point.
\end{abstract}

Keywords: liquefied natural gas (LNG), LNG tanker, spot trade, tanker based trading system

\section{INTRODUCTION}

This study proposes a new idea for liquefied natural gas (LNG) spot trades involving Japan's natural gas market.

The consumption of LNG in East Asia, particularly in China, Japan, and South Korea, has grown rapidly over the last 20 years, and most of the LNG is shipped in special tankers (henceforth, LNG tankers). The gas in these tankers is largely purchased through long-term contracts between buyers and sellers for consumption in markets where natural gas suppliers currently receive a regulated rate of return. In general, LNG trade enhances trade flexibility for both exporters and importers, rather than forcing them to rely solely on pipelines that provide fixed routes between exporters and importers. When LNG trade is possible, exporters can send their product to any location with a gasification plant, while importers can receive their gas from any location with a liquefaction plant [1].

${ }^{*}$ Corresponding author: s-hashi@main.teikyo-u.ac.jp

Received: 16 Mar 2020 Accepted: 13 Apr 2020 Published: 24 Apr 2020

Journal of Asian Energy Studies (2020), Vol 4, 9-19, doi:10.24112/jaes.040002 
In discussing the natural gas market in Asian countries including Japan, we need to consider that a large volume of natural gas is imported as LNG, and these Asian countries have not yet fully completed their transmission pipeline networks. Further, these countries are located far from primary gas mines, and tend to purchase LNG that is transported by LNG tankers because of their poor pipeline networks. For these countries, importing LNG by tanker is an alternative to importing gas via transmission pipelines. In addition, there is minimum import volume quota for fringe supplies that optimizes the consumer surplus in Lithuania [2]. Therefore, it is important to promote LNG trade to stimulate competition among natural gas supply chains.

Although Japan has an over 50-year history of LNG imports, its domestic natural gas distribution mechanisms are not designed to enable connections among markets. Japan has a limited pipeline network, and the pipelines that exist are only designed to transport natural gas a short distance from ports to largely urban areas. For example, as of December 2019, it was practically not possible to transport gas from Tokyo to Osaka via pipelines because there are tied with a pipeline but few capacities. In general, gas distribution utilities have constructed LNG terminals close to cities with large populations, and after considering the profitability of a pipeline project, they have constructed short pipelines from the LNG terminals to their urban customers. Thus, Japan's pipeline networks radiate outward from the LNG terminals in the major ports. This is in contrast to the United States, where natural gas pipelines are designed to transport gas from production fields to consumers located thousands of miles away.

In line with their high rate of economic growth in recent decades, Asian countries had to quickly construct a pipeline network to provide gas to consumers. ${ }^{1}$ Hence, the network radiated outward from LNG terminals, and was not connected with other LNG terminals. Unlike the United States and EU countries, even if third-party access (TPA) is introduced under the present situation of pipeline networks, it would be difficult to achieve full market competition. This is why market competition is not widespread in Asian countries.

However, although we need to consider technological limitations, it is possible to trade LNG between countries because there are LNG terminals in several Asian countries. Therefore, this study proposes a new approach to trading LNG and establishing LNG spot markets focusing on Japan's natural gas market.

The rest of the paper is organized as follows. Section 2 outlines the background of the LNG market in Japan, and Sections 3, 4, and 5 present the restructuring of the natural gas market, the restructuring process, and the proposed new approach, respectively. Section 6 concludes.

\section{BACKGROUND}

\subsection{Related literature}

There have been several previous studies on this topic. Vivoda [3] noted the importance of diverse LNG strategies in countries such as Japan and South Korea, while Vivoda [4] found that international trade in LNG was dominated by long-term contracts because the significant capital costs involved (e.g. for liquefaction and regasification facilities) and the inherent inflexibility in the value chain required contractual arrangements to protect both the suppliers and the buyers. Lee et al. [5] found that the Korean national firm KOGAS, which depends on LNG as a source of gas and requires additional capital facilities for shipping, storage, and regasification, had a lower level of productivity than firms that acquired their gas through pipelines.

Gkonis and Psaraftis [6] suggested that competing companies must take into account a capacity that each company supplies to the LNG shipping market. Cabalu [7] and Hartley [8] found that as

\footnotetext{
${ }^{1}$ For example, Japan experienced annual economic growth of around 10\% from 1955 until 1972.
} 
a result of technological innovations in relation to transport, LNG transport costs were decreasing significantly and the volume of LNG imports and exports was gradually increasing. Siliverstovs et al. [9] analyzed the relationships between LNG prices and prices on the Henry Hub and the National Balancing Point, as well as crude oil prices. Xunpeng [10] highlighted the importance of spot markets and hub markets in Asia because the intraregional pipeline network is largely non-existent in East Asia. However, few studies have focused on the question of how to establish spot and futures markets for natural gas in Asia.

\subsection{LNG imports and contracts}

Twenty-nine countries imported LNG in 2014 [11], with Japan ranked as the largest LNG importer, followed by China and South Korea, Table 1 shows LNG imports by country for 2017.

Table 1: LNG imports in 2017

\begin{tabular}{lcc}
\hline Country & Imports (billion cubic meters) & Share (\%) \\
\hline Japan & 113.9 & 29.0 \\
China & 52.6 & 13.4 \\
South Korea & 51.3 & 13.0 \\
India & 25.7 & 6.5 \\
Spain & 16.6 & 4.2 \\
Turkey & 10.9 & 2.8 \\
France & 10.8 & 2.7 \\
Italy & 8.4 & 2.1 \\
Others & 103.2 & 26.2 \\
Total & 393.4 & 100 \\
\hline Source: $[12]$ & &
\end{tabular}

In particular, Japan, South Korea, and China rely on LNG for nearly all of their gas requirements. LNG demand has increased rapidly in East Asia in recent decades as a result of both high economic growth and increased thermal power generation. China has continued its strong economic performance, while Japan needs large volumes of LNG to generate electricity that was previously obtained from nuclear generators (see, for example, [13]).

Almost all of the incumbent gas companies in Asian countries have vertically integrated supply chains [10]. This section illustrates Japanese LNG contracts as an example.

Tokyo Gas and other Japanese LNG importers, who are currently vertically integrated and regulated monopolists, generally purchase LNG on long-term contracts with fixed destination clauses. The Japanese government requires retailers to maintain "security of supply" in their monopoly areas (Gas Business Act, Article 16), which encourages suppliers to enter into long-term contracts. Security of supply is of political concern because Japan is heavily dependent on LNG imports. Table 2 shows the main long-term contracts of the Tokyo Gas group. In 2010, The Tokyo Gas group's share of Japan's LNG imports was 16.2\%. ${ }^{2}$ Tokyo Gas engages in contracts with firms from several countries, including Australia, Russia, Qatar, and the United States, and the minimum length of these contracts is 10 years.

\footnotetext{
${ }^{2}$ Tokyo Gas's LNG import volume for 2010 was 13.9 million tons (see Tokyo Gas CSR report; http://www.tokyogas.co.jp/csr/report_e/rightmenu/PDF/2016/e-csr2016_08.pdf), while Japan's total import volume was 85.6 million tons (see the IGU World LNG Report, p. 10; http://www.igu.org/download/file/fid/2123).
} 
Table 2: Tokyo Gas Long-term LNG Contracts

\begin{tabular}{|c|c|c|c|c|}
\hline Project name & $\begin{array}{l}\text { Annual contracted quantity } \\
\text { (1000 tons })^{*}\end{array}$ & $\begin{array}{c}\text { Starting } \\
\text { year }\end{array}$ & $\begin{array}{l}\text { Dura- } \\
\text { tion }\end{array}$ & $\begin{array}{c}\text { Contract } \\
\text { type }\end{array}$ \\
\hline Brunei & 1000 & 1973 & $20+20+10$ & Ex-ship \\
\hline Malaysia 1 & $\begin{array}{l}(1983-2017) 2600 \\
(2018-2023) 500\end{array}$ & 1983 & $20+15$ & $\begin{array}{l}\text { Ex-ship, } \\
\text { FOB }\end{array}$ \\
\hline $\begin{array}{l}\text { NWS (North West Shell) } \\
\text { (Australia) }\end{array}$ & 530 & 1989 & $20+8+7$ & Ex-ship \\
\hline Malaysia 2 & 900 & 1995 & $20+10$ & Ex-ship \\
\hline Qatar & 350 & 1998 & 24 & Ex-ship \\
\hline Malaysia 3 & 340 & 2004 & 25 & FOB \\
\hline $\begin{array}{l}\text { NWS Expansion } \\
\text { (Australia) }\end{array}$ & 1073 & 2004 & 25 & FOB \\
\hline Darwin (Australia) & 1000 & 2006 & 17 & FOB \\
\hline Sakhalin 2 (Russia) & 1100 & 2009 & 24 & FOB \\
\hline Pluto (Australia) & 1500 & 2012 & 15 & $\begin{array}{l}\text { Ex-ship, } \\
\text { FOB }\end{array}$ \\
\hline $\begin{array}{l}\text { Queensland Curtis } \\
\text { (Australia) }\end{array}$ & 1200 & 2015 & 20 & Ex-ship \\
\hline Gorgon (Australia) & 1100 & 2016 & 25 & FOB \\
\hline Ichtlhys (Australia) & 1050 & 2018 & 15 & FOB \\
\hline Cove Point (USA) & 1400 & 2018 & 20 & FOB \\
\hline Cameron (USA) & Approximately 720 & $(2020)$ & 20 & Ex-ship \\
\hline Mozambique LNG & $2600^{*}$ & $(2020$ 's) & 20 & Ex-ship \\
\hline
\end{tabular}

${ }^{*}$ One million tons of LNG is equivalent to 1.38 billion cubic meters of natural gas.

${ }^{* *}$ Ex-ship contract" means that the seller is responsible for all charges up to the port of destination, but the buyer has to pay all subsequent charges such as customs duty and taxes. FOB (Free on Board) contract means that the seller is responsible for all costs involved in delivering the goods to the export port designated by the buyer.

${ }^{* * *}$ Co-Purchase with Centrica (Source: [14])

With no transparent wholesale markets in East Asia, LNG prices are not determined directly by the forces of natural gas supply and demand. Rather, the LNG price is generally decided by direct negotiations between sellers and buyers. In East Asian countries, LNG prices are often determined on the basis of a formula linking the price of LNG to the contemporaneous price of crude oil. For instance, the LNG price for shipments to Japan is generally determined on the basis of the Japan crude cocktail (JCC) price index. The LNG price function usually takes the form:

$$
L N G \_ \text {price }=(a \times J C C)+b
$$

where the positive constants " $a$ " and " $b$ " are negotiated between the trading partners. Vivoda [4] reports that the value of the "a" coefficient is often $1 / 6$, while the value of the " $b$ " coefficient represents a price premium. (See Choi and Heo [15] for a discussion of price premiums.) To protect sellers and buyers in the case where the oil price fluctuates beyond its expected range, LNG price contracts generally include an "S-curve" clause, which sets minimum and maximum prices (see, for example, [16]).

Oil indexation played a positive role in the early stage of development of the natural gas 
industry [10]. Oil-price-linked contracts arose for two reasons. First, there is no "market" price for natural gas in East Asia. Without domestic LNG spot and futures markets, it would appear that the closest available proxy for the price of natural gas is the regional price of oil. However, when the price of oil rises or falls, the resulting price changes may not be related to the relative scarcity and economic value of natural gas. S-curve clauses are attempts to limit this problem, but they cannot fully eliminate it.

The second reason for indexing to the oil price was that the import of natural gas has had the role of substituting that of crude oil on the electricity generation sector in the 1970s and 1980s. However, this situation has changed, as the share of electricity generated using oil has declined significantly (see Figure 1). In 1970, production using oil accounted for almost 60 percent of Japanese electricity production, but by 2015, that figure had fallen to less than 11 percent.

Alim et al. [17] suggest that the Japan-Korea Marker, which is determined by surveys of the price of various LNG shipments in Northeast Asia, might serve as a viable substitute for oil price indexation. However, the difficulty here is that price indexes determined by surveys are prone to market manipulation, as traders have incentives to misreport prices (see [18]).

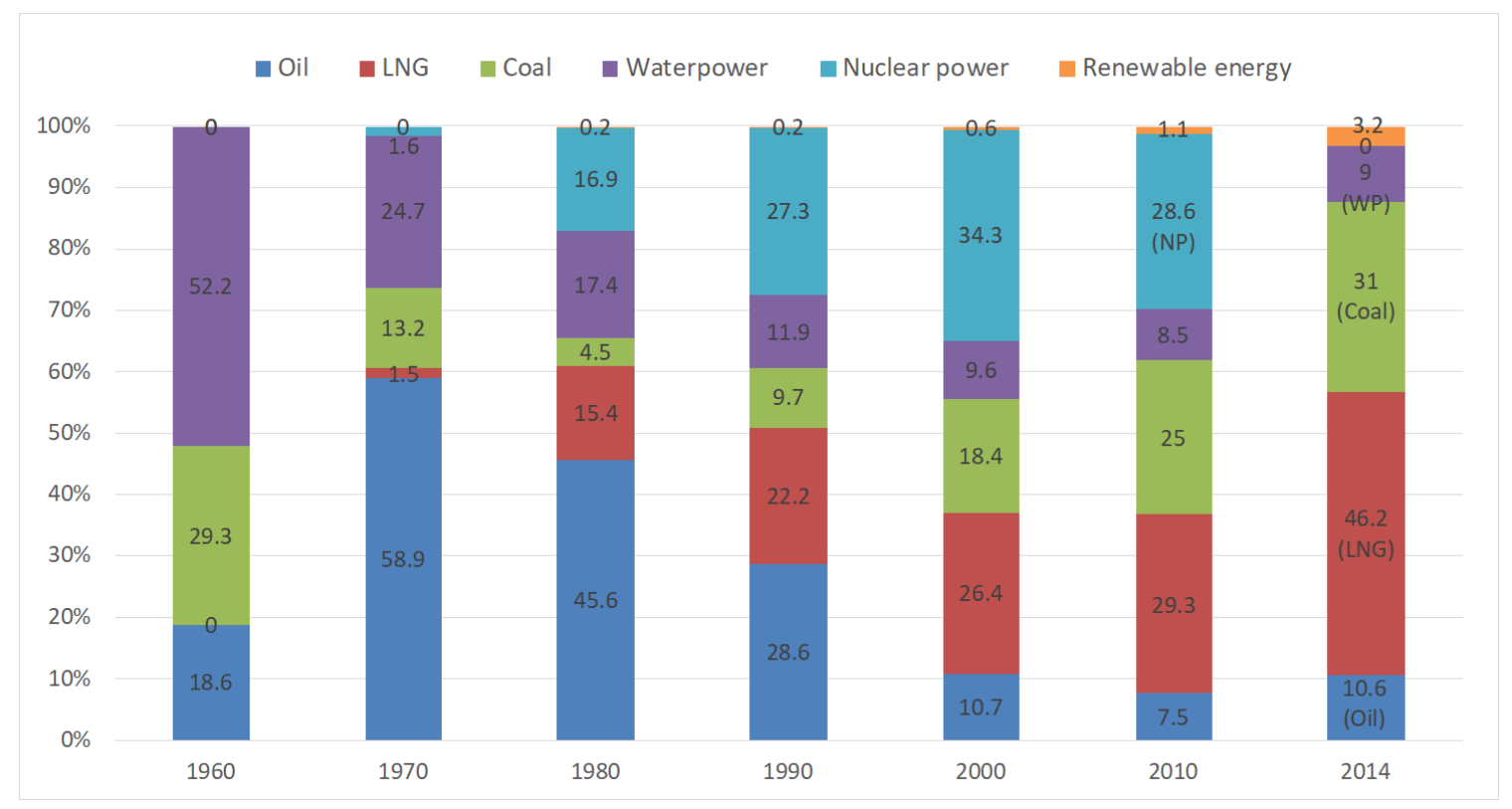

Figure 1: Percentage of electricity production from various inputs from 1960 to 2014 (Source: [19])

\section{RESTRUCTURING THE NATURAL GAS MARKET}

Japan imports almost 100\% of its natural gas in liquefied form through 35 regasification facilities located around the country. The gas is distributed through vertically integrated and regulated natural gas companies, which own the gasification plants, pipelines, and local distribution systems.

Figure 2 shows the locations of Japanese LNG ports, pipelines, and regasification systems. Note that eight of the 35 regasification plants in Japan are not on the main island of Honshu, and thus are not connected via pipelines to Honshu consumers. Even on Honshu, there are only shipments between areas in the north of the island. While there are physical pipelines running south from Tokyo to Okayama in southwestern Japan, no gas flows between the cities, and the 


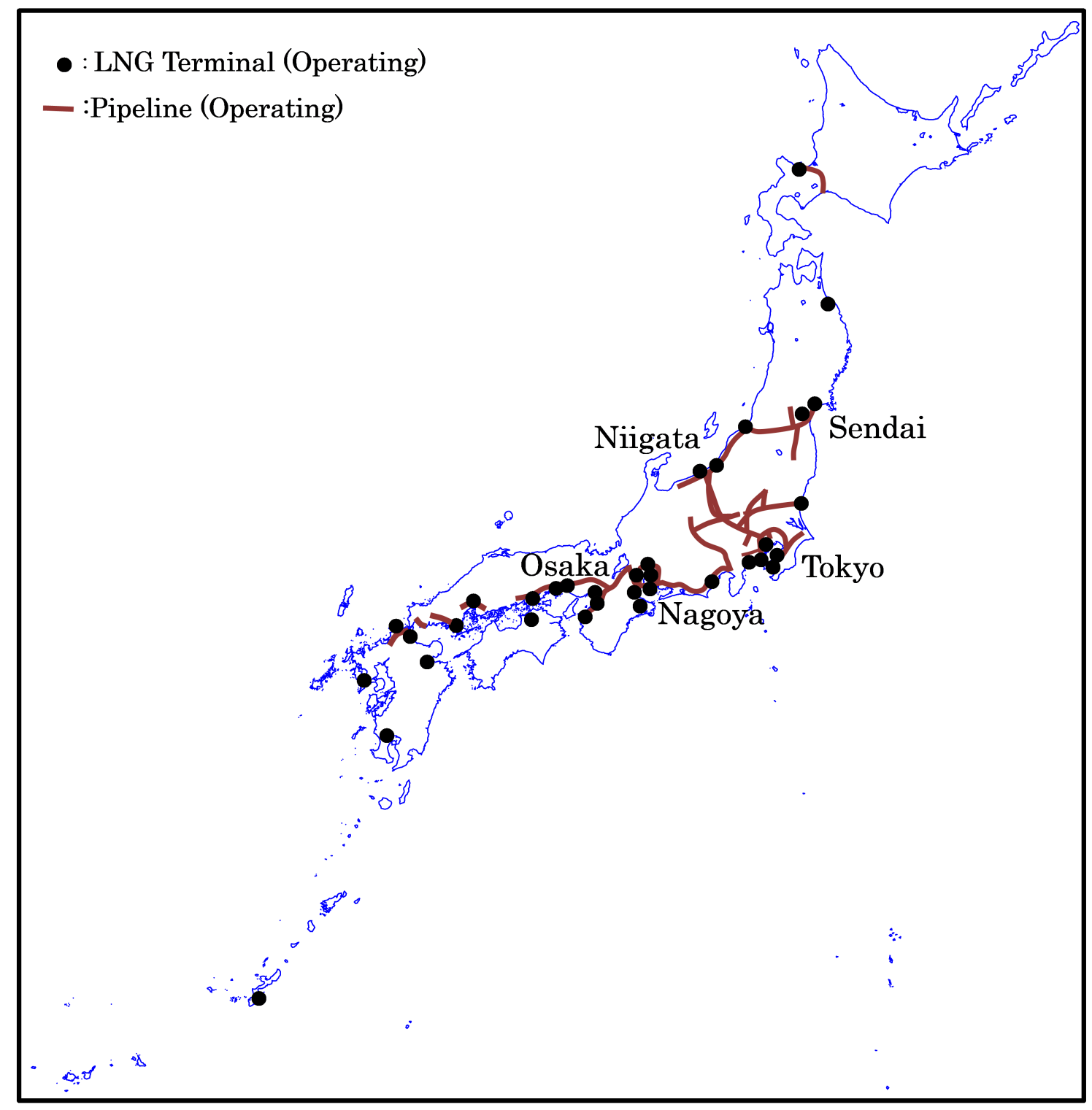

Figure 2: LNG regasification plants and pipelines in Japan (Source: [20] 
capacity of the connecting pipelines is extremely limited. ${ }^{3}$

Table 3 shows Japanese LNG regasification capacity by region. Although there are 35 LNG terminals with regasification facilities totaling 18,983,000 kl in capacity, it is difficult to deliver gas between the various areas via pipelines. For example, the Tokyo area has a large storage capacity. In particular, Niigata has a large capacity compared with the volume of gas consumption in the area. However, it can only provide extra gas to Tokyo and Sendai via pipelines. The poor pipeline network means that the areas listed in Table 3 have difficulty in delivering extra gas to other areas. Under this situation, importers cannot manage their inventory of natural gas efficiently. Furthermore, gas spot markets may not be able to be established, even if the market is liberalized.

Table 3: LNG Regasification Capacity by Region (2017)

\begin{tabular}{lccc}
\hline Area & Number of LNG facilities & Total capacity $(1000 \mathrm{kl})$ & Capacity $(\%)$ \\
\hline Northern Japan & 5 & 2,680 & 10.6 \\
Tokyo & 6 & 6,510 & 34.3 \\
Nagoya & 7 & 3,217 & 16.9 \\
Osaka & 5 & 3,725 & 19.6 \\
Southern Japan & 5 & 1,810 & 9.5 \\
Isolated & 7 & 1,701 & 9.0 \\
Total & 35 & 18,983 & 100.0 \\
\hline
\end{tabular}

Source: [14]

\section{Restructuring PROCEsS}

Japanese natural gas markets have undergone partial restructuring. Gas and electricity market reforms were simultaneously commenced in 1995, and both markets have gradually been liberalized. In the reform of 1999, the government instituted TPA and introduced a price cap regulation scheme [21]. To pursue more intensive market competition, the government plans to introduce unbundling regulations in 2022 that will separate incumbent gas utilities into a transmission company (a pipeline company) and a distribution company (a supplier) in the Tokyo, Osaka, and Nagoya areas. The transmission company will be subject to natural monopoly regulation, and the regulatory authority will enforce TPA charges on a cost of service basis. In contrast, the distribution companies, excluding some in noncompetition areas, will, in principle, be faced with market competition in the retail market [22].

The regulatory authority also plans to introduce TPA to LNG storage tanks, although it does not plan to introduce TPA to regasification facilities and pneumatic natural gas storage tanks. However, a gas futures market has never been developed in Japan, and there are no concrete plans to create a Japanese trading hub despite Japan's presentation of a Strategy for LNG Market Development at the G7 Kitakyushu Energy Ministerial Meeting in 2016. ${ }^{4}$

One barrier to establishing Japanese natural gas markets is the destination clauses in LNG contracts. Under these clauses, even if an importer has extra gas in an area, it cannot sell the extra gas to other areas via domestic markets. Ritz [23] suggests that destination clauses are designed to facilitate the exercise of market power through price discrimination. These clauses are illegal in Europe, as they are thought to be designed to restrict competition. There seems to be no obvious

\footnotetext{
${ }^{3}$ See the Ministry of Economy Trade and Industry's energy committee's sixth handout (in Japanese) (http://www.meti.go.jp/committee/sougouenergy/sougou/kiban_seibi/001_06_00.pdf), 62.7\% (2010).

${ }^{4}$ Available at http://www.meti.go.jp/press/2016/05/20160502006/20160502006-1.pdf.
} 
efficiency rationale for destination requirements [24]. However, Vivoda [4] reports that there has been a recent decline in the usage of destination clauses.

\section{A NEW IDEA}

This section introduces a new idea for LNG spot trading and market activation. ${ }^{5}$

Japan does not have long-distance trunk pipelines, and the pipelines it does have radiate from the numerous LNG ports to local areas. This study proposes an LNG tanker-based trading system similar to the open access pipelines in the United States and the UK.

Against this background, we propose an LNG tanker-based trading system as follows. First, a consortium of energy buyers from Japan would be established under the direction of the Japanese government. Buyers could constitute city governments, gas marketers, incumbent utilities, or other interested parties including trading companies and LNG tanker owners. Each buyer would contribute an amount to establish the consortium, and shares in the consortium would be a function of how much each owner contributed. For example, if a firm contributed 10 percent of the total capital required, it would be granted a 10 percent share of the consortium. The consortium would buy or lease tankers to be used to ship LNG to Japan. The consortium would also operate a commodity exchange based on those tankers, similar to other exchanges, but with the additional rules listed below. Firms would benefit from the consortium because they would have a suitable mechanism for price discovery. Shares in the consortium may or may not be tradable.

Second, the destination of any tanker in Japan would be determined by the time it reached a particular "determination" point. The departure point or Singapore is the obvious location for the determination point, but other places could be considered. We indicate that the closer the determination point is to Japan, the more responsive this market would be to the Japanese market. However, it may take some time to arrange to dock a tanker in a particular port, or it may even be impossible to dock a tanker in a specific port because of differences in terms of rolling arms and gangway gauges (the passageway between a vessel and land). At the outset, trade would only occur between the ports with same rolling arms and gangway gauges.

Third, the quantity of gas in a tanker would be broken down into relatively small units. For example, a unit could consist of one-hundredth of the capacity of a standard-sized tanker. This would eliminate the problem posed by using LNG tankers as the standard trading size.

Fourth, buyers at each delivery point would submit schedules of bids for natural gas in the same way that suppliers submit bids in U.S. electricity markets.

Fifth, bids from each delivery point would be aggregated, and the port with the highest clearing price after accounting for delivery costs would be deemed the destination port where the gas would be delivered. This price, minus any additional costs involved in shipping to this port from the lowest cost port, would be the initial "futures price." (Conceptually, it would be possible for a tanker to deliver cargo to more than one port.) Prices would then evolve through trading during the remainder of the tanker's voyage.

In addition, as is done now with long-term contracts, boil-off gas would need to be accounted for [25]. The longer the journey, the more gas boils off. ${ }^{6}$

Sixth, the Japanese government would make destination clauses on LNG shipments illegal for the reasons discussed above.

Seventh, to avoid market manipulation, only consumers could purchase this LNG. If producers had purchasing rights, they would have the incentive to increase the price, thereby enhancing

\footnotetext{
${ }^{5}$ This idea is based on the result of Tokyo Gas surveys.

${ }^{6}$ Mikami [25] found that one unit of LNG incurred 0.0015 units of boil-off per day. Thus, if a consignment of LNG was held in a tank for one year, about 42 percent of the original volume of LNG would boil off.
} 
the value of their related physical holdings and financial positions. Purchases related to the open-access tanker would have to be carefully monitored by the Japanese government for similar reasons. The problem here is that unlike traditional exchanges, the amount of product traded would be limited, making manipulation easier to achieve.

Eighth, all revenues would be received by the consortium. Any profits would be paid to consortium members based on their ownership shares.

The most important reason for proposing a new LNG tanker-based trading system is that new entrants would be able to enter the gas retail market more easily. New entrants do not need a full LNG tanker shipment upon entry into the market. Therefore, the proposed LNG tanker-based trading system would have a significant impact on new entrants.

The second reason is that a short-run futures market could be established based on the LNG trading price described above. If shares in the consortium were tradable, both producers and consumers would be able to hedge on this futures market.

Under this plan, tankers owned or leased by the consortium would be the equivalent of open-access pipelines such as those in the United States and the UK. The tanker owners would be paid for their services, but would not be committed to supplying a firm or region. The consortium would gain the profits (and bear the losses) from the combination of buying gas and leasing tankers and then selling the gas at auction, but it would not control the destination of the natural gas. Of course, the platform price could be used by other purchasers and consumers of natural gas in East Asia.

However, this presents another challenge. The quality of gas extracted from one gas field is not the same as that of gas extracted from another field. ${ }^{7}$ When LNG of a particular quality is combined with LNG of a different quality in the same tank, the mixture must be continuously stirred. Thus, storage tanks will be required to possess the necessary stirring technology. In addition, the gauges of rolling arms and gangways will need to be standardized. Only when these measures are in place can various kinds of LNG can be purchased.

\section{CONCLUSIONS}

Japan has imported LNG via LNG tankers for over 50 years. However, there are no practical spot markets in relation to domestic supply chains. This study proposes a new approach to creating LNG spot markets in Japan. Tanker-based LNG trade may be able to enhance the market efficiency of East Asian countries including Japan because these countries generally have complementary supply chains and poor pipeline networks. In particular, the fragmented pipeline system in Japan does not allow for a land-based commodity market. Therefore, in order to connect Japanese domestic markets, we propose a tanker-based trading system owned by a consortium of Japanese firms and supported by the Japanese government. This would enable a single tanker load of natural gas to be converted into hundreds of easily tradable units. In this way, a spot market for natural gas in Japan and East Asia can be created using LNG tankers.

A natural gas trading hub similar to the Henry Hub and the National Balancing Point is crucial if successful restructuring of natural gas trading is to occur in Japan. A natural gas trading hub will allow for price signals that promote a competitive natural gas supply industry. Unlike a formula linking the price of crude oil, a spot market price would allow price decision mechanism to be transparent and for proper investment decisions in relation to pipeline networks and natural

\footnotetext{
${ }^{7}$ For example, natural gas produced in Kenai (Alaska) contains CH4 (99.4\%), C2H6 (0.1\%), and N2 (0.5\%), that produced in Lumut (Brunei) contains CH4 (88.2\%), C2H6 (4.8\%), C3H8 (3.7\%), and C4H10 (1.6\%), that produced in Badak (Indonesia) contains $\mathrm{CH} 4(87.4 \%)$, $\mathrm{C} 2 \mathrm{H} 6(4.5 \%)$, and C3H8 (2.8\%), and that produced in Port Moresby (Papua New Guinea) contains $\mathrm{CH} 4(88.7 \%), \mathrm{C} 2 \mathrm{H} 6$ (7.3\%), C3H8 (2.5\%), and N2 (0.3\%). (Source: [26])
} 
gas consumption and storage facilities. Furthermore, in restructured markets, suppliers will no longer be able to automatically pass on price rises to the end consumers. Large end consumers will have incentives to seek out better prices in shorter-term markets [23]. Therefore, a spot market would be crucial for the establishment of a transparent pricing mechanism.

\section{ACKNOWLEDGMENTS}

I greatly appreciate the assistance provided by Professor Andrew Kleit from Pennsylvania State University and Jin Imamori, Tokyo Gas Co. ltd.. I also thank Geoff Whyte, MBA, from Edanz Group (www.edanzediting.com/ac) for editing a draft of this manuscript. This research did not receive any specific grant from funding agencies in the public, commercial, or not-for-profit sectors.

\section{REFERENCES}

[1] Colin T, Johnson D. Global Infrastructure Networks: The Trans-national Strategy and Policy Interface. Edward Elgar Publishing, Cheltenham, 2017

[2] Schulte S, Weiser F. LNG import quotas in Lithuania - Economic effects of brasking Gazprom's natural gas monopoly. Energy Economics 2019:78:174-181.

[3] Vivoda V. LNG import diversification in Asia. Energy Strategy Reviews 2014:2:289-297.

[4] Vivoda V. Natural Gas in Asia: Trade, Markets and Regional Institutions. Energy Policy 2014:74:80-90.

[5] Lee JD, Park SB, Kim TY. Profit, productivity, and price differential: An international performance comparison of the natural gas transportation industry. Energy Policy 1999:27:679-689.

[6] Gkonis KG, Psaraftis HN. The LNG market and a game theory approach to competition in LNG shipping. Maritime Economics \& Logistics 2009:11:227-246.

[7] Cabalu H. Indicators of security of natural gas supply in Asia. Energy Policy 2010:38:218-225.

[8] Hartley RP. Long-term LNG contracts. IAEE 36th International Conference 2013.

[9] Siliverstovs B, L'Hegaret G, Neumann A, von Hirschhausen C. International market integration for natural gas? A cointegration analysis of prices in Europe, North America and Japan. Energy Economics 2005:27:603-615.

[10] Xunpeng S. Gas and LNG pricing and trading hub in East Asia: An introduction. Natural Gas Industry B 2016:3:352-256.

[11] International Gas Union. World LNG Report - 2015 Edition. 2015.

[12] BP. BP Statistical Review of World Energy. 2018. https://www.bp.com/content/dam/bp/businesssites/en/global/corporate/pdfs/energy-economics/statistical-review/bp-stats-review2018-full-report.pdf

[13] Miyamoto A, Ishiguro C, Nakamura M. A realistic perspective on Japan's LNG demand after Fukushima. Working Paper NG62. The Oxford Institute for Energy Studies. 2012.

[14] Tokyo Gas. Tokyo Gas Investors' Guide (In Japanese). 2019. https://www.tokyogas.co.jp/IR/library/pdf/investor/ig1902.pdf

[15] Choi G, Heo E. Estimating the price premium of LNG in Korea and Japan: The price formula approach. Energy Policy 2017:109:676-684.

[16] Flower A. LNG pricing in Asia, Japan crude cocktail, and S-Curves. Natural Gas in Asia: The Challenge of Growth in China, India, Japan, and Korea ed. by Stern J. Oxford Institute for Energy Studies, Oxford, 2008.

[17] Alim A, Hartley PR, Lan Y. Asian spot prices for LNG and other energy commodities. Energy Journal 2018:39:123-141. 
[18] Kleit AN. Modern Energy Market Manipulation. Emerald Publishing, Bingley, 2019.

[19] Agency for Natural Resources and Energy. Energy White Paper 2016 (In Japanese). 2016. http://www.enecho.meti.go.jp/about/whitepaper/2016html

[20] Japan Natural Gas Association. A Note for Petroleum and Natural Gas (In Japanese). 2016. http://tengas.gr.jp/asset/00032/gasnote/16note_read.pdf

[21] Hashimoto S, Yamauchi H. A study of scale economics and price differential of the city gas industry in Japan. Working Paper No.138. Graduate School of Commerce and Management, Hititsubashi University, 2012.

[22] Agency for Natural Resources and Energy. The Document No.17, Gas System Reform Subcommittee (In Japanese). 2015 http://www.enecho.meti.go.jp/committee/ council/ basic_policy_subcommittee/017/

[23] Ritz RA. Price discrimination and limits to arbitrage: An analysis of global LNG markets. Energy Economics. 2014:45:324-332.

[24] International Energy Agency. Developing a Natural Gas Trading Hub in Asia. 2013. http://www.iea.org/publications/ freepublications/publication/AsianGasHub_FINAL_WEB.pdf

[25] Mikami N. LNG sashimi theory and hub market. Review of Petroleum and Natural Gas 2006:40:29-35.

[26] NYK Line Operations Research Committee. LNG Ships Operations, Naruyamado (In Japanese). 2015. 